\title{
Konstalasi Perkembangan Industri TPT Dunia dan Posisi Indonesia Sekarang dan Dimasa Yang Akan Datang
}

\author{
Oleh : Suharno Rusdl
}

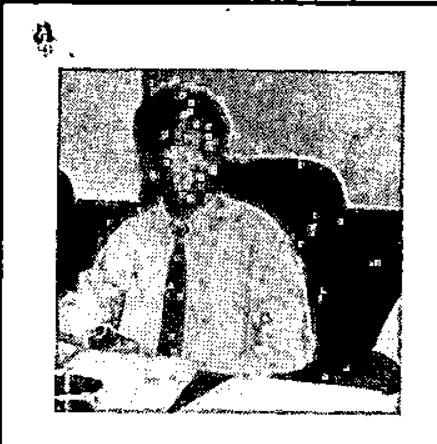

Suharno Rusdl, lahir di Pekalongan 20 Jini 1960 alumnus Fakultas Teknik UII tahun 1984. Dan S-3 diselesaikan di University Of New South Wales Australia pada tahun 1989. Saat ini sebagai dosen tetap pada almamaternya. Selain itu sebagai Konsultan pada Industrial Restucturing Proyek World Bank Departemen Perindustrian R.Idan R \& D PT. Polysindo Eka Perkasa.

\section{ABSTRACT}

Konstalasi industri tekstil dunia dalam dasa warsa terakhir ini telah banyak mengalami perubahan yang dramatis, yakni adanya relokasi besar-besaran dari negaranegaramaju ke negara-negara berkembang. Adanya transformasi teknologi yang spektakuler menyebabkan yang semula industri tekstil bersifat labour intensive kini berubah menjadi capital intensive. Adanya relokasi industri tekstil dunia mendorong berkembangnya ind̦ustri tekstil di Indonesia. Sepuluh tahun yang lalu, nilai ekspor TPT Indonesia hanya tercatat US \$1,4 juta, dan pada tahun 1992 meningkat menjadi US $\$ 6$ milyar. Namun demikian kontribusi ekspor TPT Indonesia dalam perdagangan intemasional banu sekitar 2,0\%. Dalam akhir Repelita VI Indonesia mentargetkan untuk meningkatkan eksporTPThinggamencapai
US $\$ 12,7$ milyar. Selama Indonesiamampu mengantisipasi persaingan dan proteksi perdagangan intemasional, prospekindustri ini di Indonesia masih cukup menjanjikan dalam waktu-waktu mendatang.

\section{Pendahuluan}

Konsumsi global barang tekstil dan produk tekstil (TPT) dari tahun ke tahun terus meningkat. Kalau pada tahun 1950 konsumsi TPT dunia hanya tercatat sekitar 8 juta ton, maka 40 tahun kemudian meningkat menjadi sekitar 47 juta ton, dan pada tahun 2000 mendatang kebutuhan TPT dunia diperkirakan akan mencapai 56-60 juta ton. Sejalan dengan meningkatnya permintaan, produksi TPT dunia juga terus berkembang. The Economic Intellegence Unit (EIU) melaporkan, bahwa produksi serat dunia pada tahun 1988 tercatat 37,5 juta ton, dan pada tahun 1992 meningkat 
menjadi 40,16 juta ton.

Pada tahun 1963, nilai perdagangan TPT dunia baru mencapai sekitar US $\$ 9,0$ milyar. Dua puluh tujuh tahun kemudian, walau dunia dilanda sedikit resesi, volume perdagangan industri TPT dunia ternyata tetap hampir 30 kali lipat menjadi US \$ 262,0 milyar dengan hampir $30 \%$ TPT dunia dipasarkan secara internasional.

Di bidang teknologi, industri tekstil dunia juga telah banyak mengalami perubahan yang dramatis beberapa tahun terakhir ini. Sebagai gambaran, jika pada tahun 1900 untuk memproduksi benang 1 kg diperlukan waktu selama 50 menit, maka pada masa kini untuk memproduksi benang yang sama hanya diperlukan waktu 2-3 menit. Hal yang sama juga terjadi pada proses pembuatan kain, kalau pada tahun 19.10 untuk membuat 100 meter kain dibutuhkan waktu 10 jam, maka pada jaman sekarang untuk membuat kain yang sama hanya diperlukan 30 menit. Ini membuktikan bahwa dalam kurun waktu 20.tahun terakhir ini sektor industri tekstil telah mengalami transformasi yang cukup berarti.

Pada tahun 1950-an investasi suatu pabrik pemintalan hanya memerlukan dana sékitar US \$53,600 per satu Physical Working PIace (PWP), pada tahun 1977 diperlukan US $\$ 536,000$ per PWP, dan tahun 1990, investor sedikitnya harus menyediakan dana paling tidak US $\$ 1,3$ juta PWP untuk membangun pabrik pemintalan dengan ukuran yang sama. Perkembangan serupa juga terjadi pada industri pertenunan. Kalau pada tahun 1950an untuk mendirikan suatu pabrik pertenunan hanya diperlukan US $\$ 43,550$ per PWP, dan pada tahun 1977 dipérlukan dana US $\$ 402,000$ per PWP, maka pada tahun 1990 meningkat dua kali lipat, atau .
US $\$ 804,000$ per PWP.

Padatahun 70-an, usia 15 tahun suatu mesin tekstil masih dianggap layak, sekarang usia lebih dari 10 tahun sudah dianggap ketinggalan jaman, bahkan dengan diketemukannya ellectronically data interchange, Computer Aid Design, robotics system dan perangkat-perangkat canggih lainnya. Adanya transformasi teknologi ini menyebabkan akan adanya perubahan sistem dalam industri tekstil, yang semula industri tekstil merupakan industri yang bersifat Labour Intensive, maka di masa datang akan berubah menjadi Capital Intensive Industry.

Dari gambaran singkat diatas tampak bahwa industri tekstil di dunia sekarang telah mengalami perubahan sangat berarti, baik dari segi structure, output, trade flow, investment pattern maupun technology employed. Tata niaga dan pasar industri TPT sekarang telah memasuki.dimensi baru, yakni Dimẹnsi Globalisasi:

Untuk melihat lebih jauh tentang perubahan-perubahan tersebut, tulisan ini akan mencoba mengedepankan perkembangan, konstalasi dan struktur industri tekstil di dunia, yang membahas keadaan súpply and demand masa kini, dan prospek di masa yang akan datang. Karena Indonesia sekarang termasuk sebagai negara industri dan pemasok TPT dunia, maka sebagai pelengkap, pada tulisan ini juga akan dibahas mengenai perkembangan dan posisi industri TPT Indonesia sekarang dan proyekssi di masa yang akan datang.

Konstalasi Perkembangan Industri TPT Dunia

\section{Trend Produksi Bahan Baku}

Kapas

Pada dekade tahun 70-an, seratkapas 
mendominasi produk tekstil dunia, dengạn berkembangnya serat buatan, sepuluh tahun kemudian dominasi serat kapas agar berkurang, sehingga hampir setengah produksi serat dunia dikuasai serat-serat buatan.

Menurut laporan The United State Dept. of Agriculture (USDA) yang dipublikasikan Februari 1993 lalu, tercatat bahwa produksi serat kapas dunia pada periode $1989 / 1990$ sekitar 79,8 juta bale, dan pada periode tahun berikutnya meningkat menjadi 87,0 juta bale, dan produksi periode 1992/1993 ini diperkirakan akan mencapai 87,3 juta bale. Jika ditambah dengan sisa stok tahun sbelumnya sebanyak 40,0 juta bale, maka jumlah persediaan tahun 1993, diperkirakan ada sekitar 127,3 juta bale. Catatan: konsumsi pada periode yang sama dilaporkan sebanyak 86,7 juta bale, tahun berikutnya sebanyak 85,4 juta bale, dan periode tahun 1992/1993 sedikitnya dunia akan menghabiskan kapas sebanyak 86,7 juta bale. Jika dilihat dari stok yang yakni sebanyak 127,3 juta bale, maka periode 1992/1993 ini diperkirakan akan ada sisa stok sebanyak 40,2 juta bale, dengan perincian 13,3 juta bale tersedia di RRC, dan 26,9 juta bale selebihnya berada di negara-negara AS, India dan Pakistan.

Sejak beberapa tahun terakhir ini, RRC tercatat sebagai produsen kapas terbesardunia dengan jumlah 21,0 juta bale pada tahun 1992 atau $24,1 \%$ dari total produksi dunia, kemudian disusul oleh AS 16,2 juta bale $(18,6 \%)$, India 10,0 juta bale $(11,5 \%)$ dan Pakistan 9,4 juta bale $(10,8 \%)$, dan sisanya adalah negara-negara lain. Sedangkan negara-negara konsumen kapas terbesar selama ini adalah RRC sekitar $24,2 \%$, AS $11,2 \%$, India, 10,5\%, Pakistan dan bekas Uni Sovyet masing-masing 7,8\%; Eropa Timur 6,5\%, ASEAN 4,5\% dan selebihnya adalah negara-negara lain. USDA meramalkan, bahwa konsumsi kapas tahun ini akan meningkat $0,2 \%$ dari tahùn sebelumnya.

\section{Serat Buatan}

Memperhatikan perkembangan produksi serat buatan dua puluh tahun terakhirini menunjukkan peningkatan yang sangat pesat, jika pada tahun 1970 produksi serat buatan dunia hanya tercatat 8,4 juta ton, pada akhir 1992 sudah mencapai 20,2 juta ton, atau naik $140 \%$. Dari total produksi sebanyak 20,2 juta ton di tahun $1992,85 \%$ terdiri dari synthetic fiber (polyster, nylon dan acrylic) dan $15 \%$ sisanya adalah serat cellulasic (viscos atau rayon). RRC, Taiwan dan Korea Selatan bersama-sama menguasai produksi serat buatan dunia dengan 5,1 juta ton ( $25 \%$ ), disusul AS 3,8 juta ton (19\%), MasyarakatEropa (ME) 3,6 juta ton (18\%), Jepang 1,8 juta ton (9\%) daninegara-negara lain termasuk Indonesia 5,6 juta ton (29\%).

Menurut laporan Internasional Fiber Journal edisi Januari 1993, sebanyak 170 pabrikseratbuatan (yangmeliputi perluasan dan pabrik baru) akan segera dibangun di seluruh dunia. Lebih dari sepuluh jumlah tersebut akan berada di RRC dengan 85 pabrik, Indonesia 14 pabrik, Thailand 9 pabrik, Taiwan 8 pabrik, India 7 pabrik, Korea Selatan 6, AS 8, Nigeria 5, Italia dan Turki 4, dan selebihnya berada di negaranegara lain. Sebagian besar dari pabrik tersebuit adalah untuk memproduksi serat polyster dengan total kapasitas 1,3 juta ton, dengan perincian $80 \%$ untuk membuat benang filament (POY dan FOY) dan $20 \%$ selebihnya untuk serat staple. Kapasitas 
produksi serat buatan diperkirakan akan terus meningkat beberapa tahunmendatang hingga menyamai seratkapas yangbeberapa tahun terakhir ini mendominasi produksi dunia.

Pada mulanya produksi serat synthetic berkembang di negara-negara maju seperti AS, ME dan Jepang, tetapi sejak terjadi krisis energi di tahun 1947, produksi serat tersebut mengalami pergeseran dari negara-negara industri ke negara-negara berkembang yang sering kita sebut sebagai the Rest of the World (R.O.W) terutama Taiwan dan Korea Selatan. Adanya perubahan sistem politik dan ekonomi di RRC mendorong negara tersebut untuk mengembangkan industri globalnya, tak terkecuali industri serat buatan. Beberapa tahun terakhir ini-produksi negara-negara maju seperti AS, ME dan Jepang yang semula menguasai serat dunia hampir $85 \%$ kini turun hanya menjadi $50 \%$. Taiwan dan Korea Selatan sekarang menguasai $18 \%$, danR.O.W menguasai $22 \%$. Perkembangan produksi serat buatan di Korea Selatan, Taiwan dan RRC diperkirakan akan terus meningkat beberapa tahun mendatang. Indonesia sendiri dengan tersedianya bahan baku dan untuk mengurangi ketergantungan imporkapas juga merencanakan akan terus melakukan ekspansi dalam bidang pengembangan serat buatan.

\section{Trend Kapasitas Produksi TPT Dunia}

Dibandingkan dengan kondisi dua dasa warsa yang lalu, peta kondisi permesinan industri tekstil dunia sekarang telah mengalami perubahan yang mencolok. Berdasarkan data yang dipublikasikan ITMF Agustus 1993 Ialu menggambarkan, bahwa mesin-mesin pemintalan Ring Spinning baru yang dikapalkan ke negara- negara Timur jauh mengalami kenaikan dari 53\% pada periode $1974 / 1981$ menjadi $63 \%$ pada periode $1982 / 1991$. Sementara pada kurun waktu yang sama mesin-mesin sejenis yang di install di negara-negara Eropa Timur hanya mengalami kenaikan sedikit yakni dari $6 \%$ menjadi $8,1 \%$. Sedangkan di ME justru mengalami penurunan dari $14 \%$ menjadi hanya 12,7 $\%$. Hal yang sama terjadi di negara-negara Amerika Utara yakni dari $6 \%$ menjadi 4,3 $\%$, Amerika Selatan dari $10 \%$ menjadi 6,2 $\%$ dan di Afrika turun dari $11 \%$ menjadi $5,7 \%$. Pada periode yang sama pengapalan mesin-mesin pemintalan canggih jenis Rotor Spinning ke negara-negara Timur Jauh dan Asia mengalami kenaikan 0,3\%. Hal yang sama juga terjadi pada negaranegara ME. Sedangkan pengapalan negaranegaraEropa Timur mengalami penurunan lihat gambar 8-103,4\%, ke Amerika Selatan turun $1,0 \%$, dan ke Afrika turun $0,6 \%$.

Di sektor industri pertenunan, pada periode 1974/1981 sampai dengan 1982/ 1991 mesin-mesin tenun jenis Shuttle yang dikapalkan ke negara-negara Asia dan Timur Jauh mengalami kenaikan sekitar $50,0 \%$, yakni $62,0 \%$ pada periode 1974 / 1981 naik menjadi $92,7 \%$ pada periode 1982/1991. Sedangkan hampir negaranegara yang lain, pemasangan jenis mesin tenun ini mengalami penurunan. Untuk pengapalan jenis-jenis mesin-mesin tenun yang menggunakan teknologi canggih (shutlless looms) ke negara-negara Asia dan Timur Jauh juga mengalami kenaikan dari $24,0 \%$ pada periode 1974-1981 menjadi $47,3 \%$ pada periode $1982-1991$. Pada periode yang sama pengapalan mesin yang sama negara-negara lainnya dilaporkan mengalami penurunan. Di ME turun dari $29 \%$ menjadi $21,8 \%$,-Eropa Timur turun dari $10,0 \%$ menjadi $6,1 \%$, 
Amerika Utara turun dari $20,0 \%$ menjadi $9,3 \%$, Amerika Selatan turun dari $4,0 \%$ menjadi $3,0 \%$, dan Afrika turun dari $4,0 \%$ menjadi $2,5 \%$.

Di Thailand, pada periode 1982-1991 kapasitas Ring Spinningnya meningkat $167,0 \%$ yakni dari 1,2 juta spindle menjadi 3,2 spindle, Open-End meningkat $1.150,0$ $\%$ dari 4,000 menjadi 50,000 rotor dan mesin pertenunan jenis shuttless looms meningkat $777,0 \%$ dari 570 menjadi 5000 unit. Pada kurun waktu yang sama, industri tekstil di India dan Pakistan juga mengalami kenaikan yang spektakuler. India mengalami kenaikan sebesar 22,0\% (dari 22,5 menjadi 27,4 juta spindle), dan Pakistan $36,0 \%$ (dari $4,28 \%$ menjadi 5,82 juta spindle).

Di Eropa, hanya Portugal yang kapasitas industri tekstilnya mengalami peningkatan, yakni dari 13.000 rotor menjadi 36.200 rotor, dan dari 2.900 menjadi 8.500 Shuttless Looms pada periode 1982-1991. Sedangkan untuk Ring Spinningnya mengalami penurunan sekitar $16,0 \%$, yakni dari 1,83 menjadi 1,53 juta spindle.

Indonesia yang juga dikenal sebagai the New Textile Country, industri tekstilnya juga mengalami perkembangan yang tidak jauh berbeda dengan negara-negara lain di Asia. Pada periode 1982-1991, industri tekstil Indonesia mengalami peningkatan sebesar $104,0 \%$, yakni dari 2,3 menjadi 4,7 juta spindle Ring Spinning, dari 9.000 menjadi 65.000 rotor Open End, dan dari 3.500 menjadi 65.000 unit Shuttless Loom.

Menurut laporan Biro Konsultan Ghezi yangditerbitkan bulan Agustus 1993 , dari total 4,57 juta spindle mesin Ring Spinning baru yang dikapalkan di dunia pada tahun 1991 tercatat dikirim ke negaranegara: Timur Jauh 67,0\%; ME dan EFTA
7,0\%; Amerika 5,0\%; dan R.O.W 21,0\%. Dari sebanyak 4,57 juta spindle tersebut masing-masing dikirim ke India sebanyak 1,2 juta spindle, ke Pakistan 5980.000 spindle, ke Indonesia 529.000 spindle, ke Turkey 185.000 spindle dan ke bekasnegara Uni Sovyet sebanyak 506.000 spindle.

Sedangkan untuk jenis mesin Open End Spinning, pada tahun 1991 terdapat pengapalan sebanyak 368.000 rotor, yang masing-masing dikirim ke negara-negara: Timur Jauh 17 \%; CIS $52 \%$; Eropa $8 \%$, dan negara lainnya $23 \%$. Negara-negara yang tercatat sebagai investor terbesar di dunia dalam industri pemintalan jenis Open End adalah AS, India, Turkey, Jerman, Taiwan dan Italia. Untuk industri pertenunan jenis Shuttless Loom, pada tahun 1991 Korea Selatan tercatat sebagai investor terbesar dengan 11.400 unit, kemudian disusul oleh bekas negara-negara Uni Sovyet sebanyak $\vec{k} 9.200$ unit; Jepang 5.100 unit, Indonesia 4.900 unit, Taiwan 3.600 unit, RRC2.900 unit, Thailand 2.300 unit dan AS 2.200 unit.

Perkembangan industri tekstil di negara-negara dunia ketiga berawal pada tahun 1960-1970 ketika Hongkong menggeser dominasi Jepang. Tahun-tahun selanjutnya kemudian menyusul Korea Selatan, Taiwan, Singapore, Pakistan, Indonesia, Malaysia, Pilipina dan RRC. India walaupun sebetulnya muncul lebih dulu daripada Korea Selatan, tetapi negara tersebut hanya berkonsentrasi di pasaran dalam negeri.

Dengan tujuan untuk memperluas perolehan quota dan mengejar pasar domestik yang besar, beberapa negara yang tergolong dalam the old textile country di Asia seperti Jepang, Korea Selatan, Hongkong, dan sedikit India pada sepuluh tahun terakhir ini mengalihkan industrinya 
ke negara-negara the new textile country seperti Malaysia, Indonesia, Pilipina, Mauritus dan Vietnam. Dalam 30 tahun terakhir ini bahkan ada perkiraan bahwa $50.0 \%$ industri pakaian jadi, $40 \%$ industri pemintalan, pertenunan dan perajutan, dan $25 \%$ industri serat-serat synthetic dunia mengalami relokasi ke negara-negara dunia ke tiga. Dengan adanya relokasi besarbesaranpada industri pakaian jadi ke negaranegara dunia ketiga, maka diperhitungkan pada kawasan tersebut akan terjadi permintaan kain yang cukup besar.

\section{Trend Kebutuhan TPT Dunia Pertumbuhan pasar}

Pada tahun 1990; volume konsumsi serat dunia tidak mencapai 4 jutaton, namun 50 tahun kemudian naik dua kali lipat lagi menjadi 21 juta ton pada tahun 1970 , sampai saat sekarang walaupun kecil, percepatan kebutuhan tersebut terus mengalami kenaikan dari tahun ke tahun. Pada tahun 1992 kebutuhan serat dunia tercatat tidak kurang 40 juta ton. The Economist Intelli- . gence Unit, súatu lemibaga konsultasi tekstil temama di London, meramalkan bahwa sampai tahun 2000 nanti konsumsi serat dunia akan mengalami kenaikan sampai 49 juta ton.

Pasar tekstil dunia diperkirakan akan terus meningkat di masa mendatang. Alasannya ialah pertama : adanya perkiraan kenaikan income effect di beberapa negara di masa datang, dan kedua adalah adanya kenaikan populasi dunia. Kenaikan konsumsi tekstil dunia akan dipengaruhi oleh kedua faktor tersebut.

Dilihat dari data pertumbuhan populasi yang ada sekarang, negara-negara maju sebagai penggunautama produk tekstil dunia, pertambahan penduduknya diperkirakan akan kecil di masa-masa mendatang. Sebaliknya, pertambahan penduduk di negara-negara berkembang justru terus meningkat. Hal seperti ini jika kita hubungkan antara pertumbuhan kebutuhan tekstil dan pertumbuhan pendapatan perkapita pada satu sisi dan antara kenaikan penduduk pada sisi lain, maka akan membawa implikasi bahwa pertumbuhan konsumsi TPT di negaranegara barat di masa mendatang akan rendah, dan sebaliknya pertumbuhan konsumsi di negara-negara berkembang dan negara-negara industri baru (NICS) akan tinggi.

\section{Pasar utama TPT dunia Amerika Serikat}

Walaupun akhir-akhir ini Jepang disebut:sebut sebagai negara yang ekonominya paling cerah di dunia, namún demikian dalam hal mengkonsumsi tekstil negara tersebut belum bisa mengalahkan AS dan negara-negara ME. Oleh karena itu beberapa negara, produsen tekstil dunia sampai saat ini masih mentargetkan AS dan negara ME sebagai pasar utama produk mereka.

Data terbaru yang dipublikasikan The Textile Asiaedisi Maret 1993, menunjukkan bahwa import TPT AS pada tahun 1992 mencapai 14.528 meter 2 , atau meningkat $13,8 \%$ jika dibandingkan dengan impor pada tahun 1991 yang berjumlah 12.770 meter2. Dari jumlah tersebut sekitar 50\% adalah impor dalam bentuk pakaian jadi. RRC, Taiwan, dan Hongkong adalah negara-negara pengekspor pakaian jadi terbesar ke AS dengan masing-masing mengembangkan $13,4 \%, 11,6 \%$ dan $9,7 \%$, sementara dalam ekspor produk tekstil lainnya, $\mathrm{RRC}$ masih menduduki peringkat 
utama dengan $13,7 \%$ diikuti Kanada $12,3 \%$ dan Taiwan 7,8\%.

Walaupun ekspor TPT Indonesia ke AS tahunlalumeningkatcukup tinggi, yakni $33 \%$, namun kenyataannya baru mampu menempati urutan ke 12 dibawah Pakistan, Pilipina, maupun Thailand. Adanya perlakuan khusus oleh AS terhadap Caribia dannegara-negara Amerika Latin beberapa waktu lalu, menyebabkan beberapakategori TPT Indonesia terkena call. Dengan diterapkannya Quick Response, para buyer di AS mengharuskanuntukmempersingkat delevery time, dan dampaknya adalah TPT Indonesia yang jarak tempuhnya sangat jauh sering mengalami keterlambatan.

\section{ME}

Sejak tahun 199.1, industri TPT di ME terus mengalami kemunduran, terlebih lagi dengan adanya kemelut moneter pada pertengahan 1992, menyebabkan sampai saat ini belum ada tanda-tanda untuk bangkit.

$\therefore$ Negara-negara yang tergabung
dalam Masyarakat ME telah
memperpanjang perjanjian bilateral dalam rangka MFA dengan seluruh mitra dagangnya, diantaranya ada yang diperpanjang 1 tahun dan ada pula yang 2 tahun. Khusus dengan Indonesia ME mengadakan perjanjian untuk 2 tahun dengan kemungkinan diperpanjang 1 tahun. Dan sebagai imbalannya, Indonesia mendapat up-lift pada komoditi quota dengan jumlah yang cukup berarti. Mengingat bentuk dasar MFA masih tetap berlalu bagi pasar TPT ME, maka peningkatan ekspor ke negara-negara tersebut harus dilakukan dengan hati-hati. Dalam tahun 1991, total impor TPT ME berjumlah US $\$ 44,58$ milyar. Dari total impor tersebut, andil Indonesia baru mencapai US \$ 1,34 milyar, atau sekitar $3,2 \%$.

\section{Jepang}

Jepang adalahnegaranon-quota yang mengkonsumsi TPT duniaterbesar di dunia, dan nomor ketiga setelah MEdan AS. Total nilai impor TPT pada tahun 1992 adalah US $\$ 17.339,3$ juta, atau meningkat $107,6 \%$ dari tahun sébelumnya. Melihat kenaikan pendapat per kapita negara tersebut terus merayap naik, maka diperkirakan konsumsi TPT Jepang akan naik di tahun-tahun mendatang. Jumlah terbesar TPT yang diimpor oleh Jepang adalah jenis pakaian jadi senilai US \$11.407,1 juta, atau $66 \%$ dari total nilai imporTPT. Kemudian disusul serta $12 \%$, kain $11 \%$, dan benang $7 \%$, dan sisanya adalah produk-produk TPT yang lain. Walaupun konsumsi TPT Jepang sangat tinggi, namunnegara tersebut dikenal sangat ketat dalam hal mutu produk, sehingga sangat tidak mudah untuk. memasuki pasar TPT Jepang.

\section{PERKEMBANGAN INDUSTRI TPT INDONESIA}

Seperti telah diungkapkan di bagian depan, bahwa industri tekstil sekarang merupakan industri global, oleh karenanya perkembangan industri tersebut di bagian dunia yang satu, baik langsung maupun tidak langsung akan mempengaruhi perkembangan industri yang sama pada bagian dunia yang lain, tak terkecuali Indonesia. Pada bagian ini akan di bahas mengenai perkembangan industri tekstil di Indọnesia masa kini dan di masa yang akan datang. 
Perkembangan selintas

Peran industri TPT Indonesia dalam pembangunan ekonomi nasional sudah tidak dapat disangsikan lagi. Pada awalnya industri ini dibangun dengan tujuan untuk memenuhi kebutuhan dalam negeri dan sekali gus sebagai subtitusi import. Saat ini, TPT sudah menjadi salah satu komoditi ekspor non-migas andalan Indonesia.

Lima tahun yang lalu, nilai ekspor TPT Indonesia hanya tercatat US $\$ 1,4$ milyar, atau nomor dua setelah kayu olahan, tetapi sejak tahun 1991 nilai tersebut meningkat hampir tiga kali lipat menjadi US $\$ 3,9$ milyar, dan untuk pertama kalinya menggeser dominasi nilai ekspor-kayu olahan yang hanya tercatat US $\$ 3,7$ milyar. Pada akhir tahun 1992 yang baru lalu, dilaporkan bahwa nilai ekspor TPT kita masih tetap menduduki peringkat pertama dari keseluruhan nilai ekspor non-migas dengan mencatat ekspor sekitar US $\$ 6$ milyar. Mengingat jumlah tersebut baru mencapai sekitar $2,0 \%$ dari total volume ekspor dunia, maka dalam akhir Repelitá VI mendatang, ekspor TPT Indonesia ditargetkan akan terus meningkat hingga mencapai US \$12,7 milyar.

\section{Persediaan dan Permintaan \\ Bahan baku}

\section{Kapas}

Kapas tercatat sebagai bahan baku utama dalam industri TPT Indonesia, penggunaan jenis serat ini mencapai 465.018 ton pada tahun 1992 atau sekitar $57,4 \%$ dari total penggunaan serat di Indonesia. Namun demikian sebagian besar darikebutuhan serat tersebut masih diimpor dari negara lain. Pada tahun 1992 yang baru lalu Indonesa tercatat mengimpor kapas sebanyak 422.298 ton atau sekitar $90 \%$ dari total serat kapas yang dibutuhkan. Negara asal impor kapas Indonesia adalah AS $(36,9 \%)$, Australia $(21,5 \%)$, kemudian disusul oleh Brazilia (9,4\%), Pakistan (6,7 $\%), \operatorname{RRC}(5,9 \%)$ dan sisanya dari negaranegara lain.

Keadaan imporkapas Indonesiayang terbesar dari AS adalah sangat kurang menguntungkan, sebab dengan jaraknya yang sangat jauh antara Indonesia-AS menyebabkan ongkos angkutnya menjadi sangat mahal. Di sisi lain, tersedianya fasilitas jaminan kreditlunak dari AS dalam program GSM-102 untuk kapas tidak dapat dimanfaatkan oleh industri pemintalan Indonesia, karena tidaktersedianya salah satu syarat, yaitu jaminan kredit dari Bank Pemerintah Indonesia.

Sebetulnya Indonesia sudah mampu menghasilkan serat kapas, namun jumlahnya masih sangat sedikit, yakni baru sekitar 28.000 ton pada tahun 1992, atau hanya sekitar $10 \%$ dari total kebutuhan dalam negeri. Hal ini disamping belum dikuasainya teknologi pembudidayaan kapas di Indonesia oleh bangsa kita, juga sejauh ini masih ada anggapan dari para investorbahwa usaha pembudidayaan kapas di negeri ini secara ekonomis belum memungkinkan untuk dilaksanakan. Keadaan seperti ini membuat industri TPT kita akan sangat bergantung pada kapas impor di masa yang akan datang.

Dengan meningkatnya konsumsi TPT dalani negeri dan rencana peningkatan ekspor, kebutuhan serat di dalam negeri pada tahun 1993 ini diproyeksikan akan meningkat menjadi 554.476 ton dari 465.018 ton di tahun 1992 , dan pada akhir Repelita VI mendatang kebutuhan tersebut diperkirakan akan terus meningkat hingga mencapai 971.142 ton. 


\section{Polyester}

Polyester merupakan bahan baku industri TPT terbesar kedua di Indonesia setelah kapas. Pada tahun 1989, Indonesia mengkonsumsi PSF sebanyak 111.647 ton dan meningkat hampir dua kali lipat pada tahun 1992 menjadi 199.544 ton. Sementara itu pada periode yang sama volume produksi serat polyester dalam negeri hanya 100.332 ton pada tahun 1989, dan 170.437 ton pada tahun 1992, sehingga kekurangan serat polyesteryang dibutuhkan terpaksa diimpor dari negara lain yakni sebesar 16.719 ton pada tahun 1989 dan meningkat menjadi 36.382 ton pada tahun 1992. Namun demikian pada waktu yang sama Indonesia juga berhasil mengekspor serat polyester sebesar 5.404 ton pada tahun 1989 dan naik menjadi 7.275 ton pada tahun 1992 (untuk produk tertentu).,Dengan adanya dumping dari Korea Selatan dan Taiwan pada akhir tahunlalü, industri serat polyester Indonesia sedikit mengalami goncangan. Pada bulan September 1992, harga polyester produksi dalam negeri berkisarsekitar US $\$ 2,55$ per. kg, sementara Korea Selatan menjual serat polyester hanya US $\$ 2,34$ per $\mathrm{kg}$, padahal harga di dalam negeri Korea sendiri sekitar. US $\$ 2,72$ per $\mathrm{kg}$.

Selain PSF, Indonesia juga memproduksi PFY. Pada tahun 1989 produksi PSF Indonesia tercatat hanya 145.481 ton dan meningkat menjadi 182.033 ton pada tahun 1992: Namun demikian dengan meningkatnya konsumsi dalam negeri, sampai tahun 1992 IndonesiamasihmengimporPFY sebanyak26.928 ton. Untuk tahun 1993 sekarang ini, kebutuhan dalam negeri PSF dan PFY diperkirakan masing-masing akan meningkat menjadi 246.185 ton dan 242.775 ton dari 199.544 ton dan 203.718 ton di tahun 1992. Dan sampai tahun 1997 kebutuhan tersebut akan terus meningkat menjadi 416.512 ton untuk PSF dan 386.626 ton untuk PFY.

\section{Nylon}

Serat nyylon telah dikembangkan di Indonesia sejak tahun 1973, namun demikian perkembangannya tidak sepesat polyester. Hal ini selain disebabkan permintaan akan serat jenis ini kurang banyak, juga bahan bakunya masih harus diimpor dari negara lain. Jika dibandingkan dengan perkembangan industri polyester, walau mengalami peningkatan, volume produksi serat nylon sebetulnya kurang mengalami kenaikan yang berarti dari tahun ke tahun. Pada tahun 1989 volume produksi serat ini hanya 13.05 I ton dán meningkat menjadi 20.267 ton pada tahun 1992. Sementara pada periode yang sama konsumsi dalam negeri jauh lebih besar; yakni, mencapai 14.214 ton pada tahun 1989, dan meningkat menjadi 22.456 ton pada tahun 1992. Sehingga untukmemenuhi kebutuhan yang ada Indonesia harus mengimpor serat ini dari luar negeri. Pada tahun 1989, Indonesia tercatat mengimpor serat nylon sebanyak 1.233 ton dan pada tahun 1992 meningkat menjadi 2.794 ton. Lihat gambar 19.

Proyeksi kebutuhan serat nylon di tahun ini diperkirakan akan mencapai 27.244 ton, dan akan meningkat menjadi 45.820 ton pada tahun 1997 mendatang. Mengingat sampai saat ini belum ada tandatanda investor baru yang berminat untuk mengembangkan industri serat jenis ini, maka diperkirakań impor Indonesia terhadap serat nylon akan terus meningkat di tahun-tahun mendatang.

Acrylic

Serat sintetik ketiga yang digunakan sebagai bahan baku industri tekstil di Indo- 
nesia adalah Acrylic. Penggunaan serat ini adalah untuk dipintal menjadi benang yang merupakan bahan baku industri karpet, sweater, blanket, bordir, kain.jok dan bahan boneka.

Konsumsi serat ini terus meningkat daritahunke tahun. Pada tahun 1989 tercatat 30.449 ton serat acrylic telah dikonsumsi industri tekstil kita, dan pada tahun 1992 konsumsi tersebut naik menjadi sekitar 38.666 ton. Sayangnya, walaupunkonsumsi serat ini terus meningkat, sampai saat ini Indonesia belum memiliki pabrik pembuat serat acrylic, sehingga seluruh kebutuhan terpaksa harus diimpor dari negara lain.

Proyeksi kebutuhan serat acrylic di Indonesia dalam waktu-waktu mendatang diperkirakan akan terus meningkat. Pada -tahun ini (1993), tidak kurang dari 45.165 ton serat jenis ini akan dibutuhkan industri tekstil kita, dan pada tahun 1997 mendatang diperkirakan akan meningkat sekitar $53,3 \%$ menjadi 69.004 ton.

Sejak tahun 1988 BKPM sebetulnya telah mengeluarkan SPT kepada dua perusahaan untuk mendirikan pabrik serat acrylic dengan jumlah kapasitas produksi per tahunnya sebesar 60.000 ton. Kedua pabrik tersebut sekarang sedang dalam konstruksi, dan dalam waktu dekat diharapkan dapat segera beroperasi.

\section{Rayon}

Selain serat-serat sintetik yang telah disebutkan di atas, industri tekstil Indonesia juga memerlukan serat rayon sebagai bahan bakunya. Serat rayon, atau yang sering disebut sebagai-viscose rayon staple fibre (VRSF) dihasilkan dari proses regenerasi bahan cellulose kayu Pinus.

Sampai. saat ini, Indonesia baru memiliki dua pabrik VRSF dengan kapasitas produksinya sekitar 82.800 ton per tahun, sementara dalam waktu yang sama konsumsinya mencapai 107.282 ton. Adanya permintaan yang lebih tinggi dari pada persediaan yang ada menyebabkan Indonesia selalu mengimpor serat VRSF dari tahunke tahun. Pada tahun 1989, impor VRSF tercatat hanya 3.341 ton, dan pada tahun 1992 yang barulalumeningkat hampir delapan kali lipat menjadi 26.106 ton.

Sejalan dengan meningkatnya permintaan pasar, kebutuhan dalam negeri VRSF dalam waktu-waktu mendatang diproyeksikan akan terus meningkat. Pada tahun 1993 sekarang ini saja misalnya, kebutuhan VRSF akan mencapai 128.851 ton, dan pada akhir 1997 mendatang akan meningkat sekitar $73,5 \%$ menjadi 223.513 ton. Melihat keadaan seperti itu, jika dalam waktu dekat pabrik-pabrik VRSF yang ada di Indonesia tidak melakukan ekspansi atau tidak ada pendirian pabrik-pabrik baru, maka diperkirakan impor VRSF Indonesia akan terus meningkat di masa-masa yang akan datang.

Kendala yang dihadapi oleh pabrikpabrik pembuat VRSF di Indonesia adalah, Pertama: masih belum tersedianya bahan baku yang berupa pulp di Indonesia yang cocok untuk membuat VRSF berkualitas standar. Pulp yang tersedia di Indonesia sementara ini, lebih menguntungkan untuk dibuat kertas. Akibatnya, pulp untuk bahan baku pabrik-pabrik VRSF kita sekarang masih didatangkan dari luarnegeri. Kendala kedua adalah : teknologi yang digunakan oleh pabrik-pabrik pembuat VRSF di Indonesia masih bersifat convetional yang menimbulkan limbah cukup berbahaya.

Untuk mengatasi. kendala-kendala yang dihadapi oleh industri VRSF Indonesia, perlu kiranya diperkenalkan teknologi baru mengenai pembuatan VSRF yang di kenal sebagai Sovent-System. Dengan 
teknologi ini, disamping akan mampu dihasilkan produk VRSF yang lebih baik, limbah yang berbahaya juga akan dapat dihindarkan.

\section{Industri Pemintalan}

Berdasarkan survey yang dilakukan olèh Technical Service Group for the Textile Industry baru-baru ini, sampai dengan akhir tahun 1992 jumlah penisahaan yang bergerak di sektor industri pemintalan tercatat tidak kurang dari 112 perusahaan dengan kapasitas terpasang tidak kurang dari 7.375.276 spindle Ring Frame, dan 25.856 rotor Open End. Berdasarkan survey tersebut juga tercatat bahwa pertumbuhan industri pemintalan meningkat sekitar $17,7 \%$ per tahun dalam empat tahun terakhir ini.

Dengan kapasitas terpasang sebanyak 7,4 juta spindle sebetulnya industri pemintalan mampu memproduksi benang sebanyak 1.097.519 ton/tahun. Namun dengan rata-rata efisiensi produksi sekitar $91,0 \%$, produksi nyata industri pemintalan Indonesia hanya mencapai 998.970 ton pada tahun 1992. Sedangkan kebutuhan benang pada waktu yang sama hanya sekitar 947.251 ton, sehingga kelebihan produksi yang ada harus diekspor. Ekspor benang Indonesia ke manca negara sejak beberapa tahun terakhir ini terus meningkat. Pada tahun 1989 misalnya, hanya tercatat 21.115 ton, dan pada tahun 1992 yang baru lalu naik empat kali lipat menjadi 86.936 ton.

Walau industri pemintalan indonesia sudah kelebihan produksi, temyata masih belum mampu membuat beang-benang yang bersifat khusus (Speciality Yam). Untuk mengatasi permintaan benang-benang seperti itu, Indonesia terpaksa masih mengimpor benang dari negara lain. Pada tahun 1989 Indonesia tercatat mengimpor benang sebanyak 29.198 ton, dan pada tahun 1992 tercatat menjadi 35.217 ton, atau naik sekitar $20,6 \%$.

Dengan - adanya proyek restrukturisasi di sektor industri pertenunan dengan cara memasang mesin-mesin tenun baru yang berkecepatan tinggi, kebutuhan benang di dalam negeri untuk tahun-tahun mendatang diproyeksikan akan terus meningkat. Pada tahun ini (1993) saja, diperkirakan tidak kurang dari 1.209.207 ton benang akan dikonsumsi industri pertenunan kita, dan pada tahun 1997 mendatang akan meningkat hampir dua kali lipat menjadi 2.038.716 ton. Keadaan seperti ini memberi indikasi bahwainvestasi baru di sektor industri pemintalan diperhitungkan akan masih menguntungkan. Namun demikian ada hal. yang perlu dicatat, bahwa benang yang dibutuhkan di masa mendatang adalah untuk mensupply industri pertenunan yang memiliki mesin-mesin tenun berkecepatan tinggi, sehingga dengan sendirinya benang yang dihasilkan harus berkualitas tinggi pula.

\section{Industri Pertenunan}

Menurut laporan Direktorat Jendral Aneka Industri Dept. Perindustrian, sampai akhir tahun 1992 yang baru lalu, jumlah industri pertenunan di Indonesia tercatat1.092 perusahaan, dengan total keseluruhan mesin terpasang sebanyak 248,035 unit mesin tenun. Dari sejumlah itu $88,7 \%$ (220.496 mesin) diantaranya terdiri dari Shuttle Looms, 5.2\% (12.429) jenis Rapier, 3,1\% (7.600) jenis Water Jet Looms, dan 3.0\% (7.510) selebihnya adalah jenis Air Jet Looms. Dilihat dari usia mesin tenun yang ada, $59,8 \%$ di antaranya mesin buatan sebelum tahun $1986,35,3 \%$ buatan antara tahun $1986-1990,3,9 \%$ buatan 
aritara tahun 1990-1991, dan 1,0\% sisanya adalah buatan tahun 1992 .

Volume produksi industri pertenunan tampak mengalami kenaikan yang mencolok dari tahun ke tahun. Pada tahun 1989 tercatat baru 3.145.672 ribu meter, dan,pada tahun 1992 naik 42,3\% menjadi 4.506.533 ribu meter. Pada periode yang sama sebenarnya konsumsi dalam negeri hanya mampu menyerap sekitar 2.697.152 ribu meter pada tahun 1989, dan 3.056 .316 ribu meterpada tahun 1992. Ini berarti pada periodé tersebut ada kelebihan produksi sekitar 448.520 - 1.449 .783 ribu meter. Kelebihan produksi tersebut kemudian diekspor ke luar negeri. Data yang dikumpulkan TSG-Text mencatat, pada tahun 1989. Indonesia telah mengekspor kain sebanyak 237.524 ribu meter dan meningkat $328,3 \%$ pada tahun 1992 . menjadi 1.017.327 ribu meter.

Namun demikian dengan berkembangnya industri pakaian jadi yang kadang kala membutuhkan jenis kain dengan kualitas khusus, terpaksa Indonesia masih mengimpor kain. Data yang dikumpulkan TSG-Text mencatat, bahwa pada tahun 1989 Indonesia telah mengimpor kain sebanyak 93.445 ribu meter, dan meningkat hampir tiga kali lipat menjadi 245.620 ribu meter pada tahun 1992.

\section{Industri Perajutan}

Menurut catatan Departemen Perindustrian dan BKPM, pada tahun 1989 si Indonesia hanya tercatat sebnyak 317 perusahaan pertenunan. Namun, pada tahun 1992 meningkat menjadi 357 perusahaan.

Walau kurang menggembirakan, volume produksi industri ini tercatat terus meningkat dari tahun ke tahun. Pada tahun 1989 , kapasitas produksinya baru mencapai 1.092.991 ribu meter, dan meningkat menjadi 1.586 .816 ribu meter pada tahun 1992. Sementara pada periode yang sama konsumsi dalam negeri hanya tercatat 798.546 ribu meter pada tahun 1989 , dan 1.228.566 ribu meter pada tahun 1992. Kelebihan produksi yang ada kemudian telah diekspor ke luar negeri. Laporan Data Export-Import yang diterbitkan oleh BPS baru-baru ini menunjukkan, bahwa pada tahun 1989 Indonesia berhasil mengekspor kain rajut sebanyak 339.437 ribu meter, dan meningkat menjadi 509.865 ribu meter pada tahun 1992. Sementara pada periode yang sama impor kain rajut Indonesia tercatat 44.992 ribu meter pada tahun 1989 , dan 151.615 ribu meter pada tahun 1992. Seperti halnya kain tenun, impor kain rajut Indonesia terjadi karena ada beberapa jenis kain yang belum mampu dibuat di dalam negeri.

Proyeksi kebutuhan kain rajut untuk tahun-tahun mendatang diperhitungkan akan terus meningkat. Pada tahun 1993 sekarang, diperkirakan tidak kurang dari 1.931.805 ribu meter kain rajut akan dibutuhkan Indonesia, dan kebutuhan tersebut akan naik hampir tiga kali lipat menjadi sekitar 3.304.716 ribu meter pada tahun 1997 mendatang. Untuk mengantisipasi kebutuhan tersebut, peningkatan efisiensi dan atau investasi baru di sektor industri perajutan adalah sangat perlu untuk diperhitungkan.

\section{Industri Pakaian Jadi}

Industri pakaian jadi merupakan industri paling hilirdalam rangkaian industri TPT. Industri ini mempunyai karakter labaour intensive, low capital ivesment, labour high added value dan enviromental friendly, oleh karena itu adalah sangat tepat apabila industri ini berperan sebagai Spare Head dalam industri TPT kita. 
Perkembangan industri ini sangat menggembirakan pada beberapa tahun belakangan ini. Pada tahun 1985 hanya tercatat 334 perusahaan dengan 63.658 mesin, namun pada tahun 1991 jumlahnya meningkat menjadi 546 perusahaan dengan 122.043 mesin. Sebagian dari perusahaan tersebut didirikan oleh investor asing yang merelokasikan pabriknya karenà di negaranya sudah tidakmemiliki keunggulan komparatif lagi dan tidak tersedianya fasilitas GSP (Generalized System of Preferences) dari negara-negara importir, dan sebagian yang lain didirikan oleh para pengusaha Indonesia sendiri. Berdasarkan perbandingan nilai investasinya, 70,0\% investasi pada industri pakaian jadi adalah PMA, dan 30;0\% selebihnya adalah PMDN. Negara-negara asal para investor industri pakaian jadi di Indonesia yang dominan adalah Korea Selatan, Hongkong, Taiwan dan Jepang.

Volume produksi industri pakaian jadi tercatathanya sekitar 86.502 ribu dozen pada 1989 , dan meningkat menjadi 125.400 ribu dozen pada tahun 1992. Pakaian jadi Indonesia terutama adalah untukmemenuhi pasaran ekspor. Pada tahun 1981 nilai eksporpakaianjadi Indonesia hanya tercatat US $\$ 95$ juta, maka sepuluh tahun kemudian meningkat 24 kali lipat menjadi US $\$ 2.65$ milyar. Rata-rata pertumbuhan volume ekspor sejak tahun 1983 - 1991 adalah sebesar $67,9 \%$ per tahun. Saham ekspor pakaian jadi terhadap keseluruhan nilai ekspor TPT kita sepuluh tahun terakhir ini selalu di atas 50,0\%. Melihat tingginya pertumbuhan tersebut menggambarkan bahwa investasi di sektor industri pakaian jadi untuk tahun-tahun mendatang diperkirakan masih akan inenguntungkan. Proyeksi Konsumsi TPT Indonesia Dengan meningkatnya pendapatan per kapita dan bertambahnya populasi penduduk Indonesia, kebutuhan kain dalam inegeri di tahun-tahun mendatang diperkirakan akan meningkat. Pada akhir tahun 1993, tidak kurang dari 4.525.205 ribu meter kain diperhitungkan akan digunakan oleh penduduk Indonesia, dan empat tahun kemudian penggunaan tersebut akan meningkat menjadi 6.099 .687 ribu meter. Jika ditambah dengan kebutuhan industri-industri garment untuk memproduksi pakaian jadi yang akan ekspor, kebutuhan kain dalam negeri total akan mencapai 7.165.235 ribu meter pada akhir tahun 1993, dan akan meningkat sekitar 62,6\% menjadi 11.572.155 ribu meter pada tahun 1997 (kain tenun sebanyak 8.267.439 ribu meter, kain rajut sebanyak 3.304.716 ribu meter).

Melihat kapasitas produksi kain Indonesia sekarang yang baru mencapai 6.093.349 ribu meter, maka sampai tahun 1997 mendatang akan diperlukan investasi dengan kapasitas dua kali lipat dari kapasitas sekarang.

\section{Kendala Perkembangan Industri TPT Indonesia}

\section{Hambatan Lokal}

Salah satu permasalah yang sekarang dihadapi oleh dunia usaha industri TPT Indonesia adalah diterapkannya suku bunga yang tinggi. Kebijaksanaanuang ketat yang diberlakukan beberapa tahun lalu terbukti telah menghambat daya saing. TPT kita baik di pasar internasional maupun di pasar domestik. Melihat suku bunga yang tinggi beberapa pengusaha TPT Indonesia masih enggan untuk melakukan rehabilitasi maupun modemisasi mesin-mesin yang dimilikinya, kendatipun secara teknis 
ekonomismesin-mesin tersebut sudahtidak laik lagi untuk digunakan. Perlu diketahui bahwadanaProyekRestrukturisasilndustri (IRP) yang dibiayai oleh Bank Dunia pada tahun 1989, hingga kini masih banyak tersisa di beberapa bank.

Disamping itu, sebagian besar industri TPT Indonesia tidak didukung oleh Market Management yang bagus. Hasil monitoring TSG-Text yang dilakukan beberapa bulan lalu menemukan, bahwa para pengusaha TPT kita masih banyak yang belum memiliki Market Oriented. Selain itu, efisiensi mesin-mesin yang digunakan juga masih tergolong rendah.

Masalah lain yang sudah diketahui oleh umum adalah, bahwa ketergantungan imporbahan baku terutama kapas dan rayon untuk industri TPT kita masih tinggi. Impor kapas Indonesia pada tahun 1992 tercatat sebesar 442.298 ton, atau hampir sepadan dengan jumlah produksi seluruh serat dalam negeri pada tahun yang sama. Panjangnya birokrasi perijinan untuk mendirikan perusahaan juga masih sering menjadi keluhan beberapa calon investor, terutama investor asing yang berminat menanamkan usahanya di Indonesia.

Sebagian industri TPT kira sekarang hanya mengandalkan kapasitas dan kurang didukung oleh-kemampuan untuk memproduksi barang-barang yang bermutu tinggi, akibatnya nilai tambah yang diperoleh sangat kecil. Disamping itu, walaupun sebagian industri TPT kita ditujukan untuk ekspor, namun produkproduk yang dibuat masih banyak yang menggunakan lisensi dari manca negara. Hal ini konsekwensinya apa bila di negara tujuan ekspor terjadi resesi atau struktur industrinya mengalami pergeseran, akan mengakibatkan goncangan pada industri TPT kita.
Untuk memperoleh nilai tambah yang tinggi dan kestabilan yang langgeng, perlu dikembangkan kreasi untuk menciptakan produk-produk baru yang mampu bersaing di pasar. Untuk itu diperlukan sarana dan fasilitas pengembangan sumber daya manusia yang handal.

Sampai saat ini, beberapa lembaga pendidikan tekstil yang ada di Indonesia kurang lengkap dengan sarana laboratorium yang cukup memadai, terutama untuk laboratorium serat buatan, desain dan tekstil non-woven. Hal ini di satu sisi menyebabkan kita akan selalu tergantung pada tenaga ahli dari manca negara, dan di sisi lain juga hasil industri TPT kita tidak akan mampu menjadi market leader.

\section{Ancaman Global}

Selain menghadapi kendala dari dalam negeri, industri TPT Indonesia juga menghadapi ancaman dari luar, yakni adanya negara-negara pesaing dan kebijaksanaan proteksionitis dari negaranegara maju. Di antara negara-negara pesaing tersebut adalah :

\section{RRC}

Dengan adanya pembaharuan sekitar 3 juta spindle dan penambahan 7 juta spindle untuk jangka waktu 1991-1995, kapasitas produksi TPT RRC diperkirakan akan meningkat. Nilai ekspor TPT RRC pada tahun 1990 tercatat hanya sekitar.US \$ 14 milyar, dan pada tahun 1992 naik mendekati dua kali lipat menjadi US $\$ 24$ milyar, dengan pertumbuhan rata-rata $43 \%$ untuk produk tekstil, dan $73 \%$ untuk produk pakaian jadi.

Walaupun dalam dasa warsa 80-an RRC sudah melewati AS sebagai produsen kapas terbesar duniạ, namun 
peningkatannya temyata lebih rendah dari kebutuhan doméstiknya. Sedangkan musim tanam tahun ini diperkirakan kualitasnya tidak mengalami ketinggalan jika dibandingkan dengan industri TPT lainnya. Namun demikian, jika RRCtetap mendapat fasilitas MFN dari AS seperti sekarang, negara dengan kemampuan teknologi dan sumber daya manusia sedikit di atas Indonesia, ditambah dengan biaya tenaga kerja yang sangat rendah, dimasa mendatang diperkirakan negara ini akan sangat sukar ditandingi oleh Indonesia.

\section{Taiwan}

Taiwan, walau termasuk negara kecil, negara ini memiliki industri TPT yang kuat di dunia. Dengan sekitar 5 juta spindle dan 80.000 Shuttless Looms, sebetulnya kapasitas produksi TPT kita negara ini berada di bawahindonesia. Tetapi dengan tingginya kemampuan dagang yang dimiliki, negara ini mampu memasok TPT dunia sebesar US $\$ 10,5$ milyar pada tahun 1990, sekitar 10 kali kemampuan Indonesia pada tahun yang sama.

Sejak tahun 1992 lalu, Taiwan dan RRC telah melakukan hubungan perdagangan secara langsung, pada tahun yang sama. Taiwan juga telah memulai menanamkan saham industri TPT nya di RRC. Kerja sama semacam itu, dalam waktu mendatang diperkirakan akan dapat meningkatkan industri TPT di kedua negara tersebut. Dengan dibukanya penerbangan langsung Ho Chi Minh City-Taipe, Taiwan juga diperhitungkan akan dapat memperlancar arus perdagangan TPT nya ke negara lain, dengan cara menggunakan fasilitas-fasilitas ekspordari negara-negara maju yang diberikan kepada Vietnam. Dan yang perlu diperhatikan lagi, dalam menghadapi abad ASIA mendatang, pemerintah Taiwan merencanakan akan menjadikan seluruh pulau Taiwan sebagai zona perdagangan bebas.

Hongkong

Sejak 20 tahun terakhir ini, TPT menjadi penghasil devisa utama bagi Hongkong. Pada tahun 1990, ekspor TPT seluruhnya mencapai US $\$ 23,6$ milyar. Hongkong merupakan pemasok terbesar kedua pakaian jadi setelah Italia, dan pemasok pasaran produk tekstil dunia terbesar ketiga setelah Jerman dan Italia. Dengan terus ditingkatkannya teknologi permesinan di Hongkong, negara ini bertekad untuk tetap berada di garis depan dalam pengadaan produk tekstil jenis baru untuk pakaian jadi: Terlebih lagi, masyarakat Hongkong yang telah terbukti memiliki keahlian dalam berdagang, maka segala bentuk perkembangan industri TPT di negara ini patut diperhatikan terhadap ancaman industri TPT kita.

\section{Korea Selatan}

Disamping RRC, Hongkong dan Taiwan. Korea Selatan juga termasuk negara terbesar pemasok TPT dunia. Dengan memiliki jumlah spindle yang lebih sedikit dari pada Indonesia, Korea Selatan ternyatamampumenghasilkan benanglebih banyak dari pada Indonesia. Pada tahun 1991 produksi benang Korea Selatan tercatat 1.800 ribu metrik ton, sementara pada tahun yang sama Indoneșia hanya manpu memproduksi sebanyak 1.027 ribu metrik ton. Hal ini menggambarkan efisiensi industri pemintalan di Korea Selatan lebih tinggi dari pada Indonesia. Begitu pula dalam hal pemasok pakaian jadi, Korea Selatan pada tahun 1990 berada pada posisi nomor empat terbesar setelah Hongkong, Italia dan RRC. Total ekspor TPT pada tahun 1990 tercatat sebesar US $\$ 14,1$ milyar. Dengan pesatnya perkembangan industri serat-serat synthetic di sana 
menyebabkan beberapa tahun terakhir negara ini telah kelebihan stok, dan akhimya stok tersebut dijual dengan harga dumping ke beberapa negara lain, termasuk ke Indonesia.

Kebijaksanaan Proteksionis Negaranegara Maju

Dalam era globalisasi sekarang ini, sistem perdagangan TPT internasional diliputi oleh adanya kebijaksanaan proteksionistis dari negara maju. Salah satu bentuk proteksi tersebut diantaranya adalah General Agreement of Tariffs and Trade (GATT).

Seperti halnya dengan produk lain, mula-mula perdagangan TPT dunia diatur melalui GATT, yang telah diberlakukan sejak tahun 1948. Namun sejak tahun 1961 di perdagangan tersebut diatur melalui Short-term Textile Arrangement (STA). Kemudian dilanjutkan dengan Long-term TextileArrangement (LTA) dengancakupan produk TPT yang terbuat dari kapas saja. Pada prinsipnyaLTA membolehkan adanya restriksi perdagangan dalam bentuk quota yang diterapkan secara diskriminatif, yaitu terhadap negara-negara berkembang. Namun dengan disepakatinya Multi Fiber Arrangement (MFA) pada tahun 1973, pengaturan tersebut menjadi lebih restriktif, karena di dalamnya memasukkan TPT yang terbuat dari serat buatan.

Adanya MFA, pada awalnya industri TPT Indonesia ikut terbantu dalam menembus pasaran internasional, namun sejak Indonesia dianggap sebagai negara pengekspor utama TPT dunia, yakni pada tahun 1979 maka pada saat itu Indonesia masuk dalam daftar yang terkena quota. Sehingga adanya MFA sudah tidak menguntungkan lagi, bahkan menjadi hambatan.

Dengan munculnya blok-blok perdagangan baru seperti Europe Single Market dan North American Free Trade Agreement(NAFTA) mengakibatkan cerita Uruguay Round menjadi tidak menentu. Terbentuknya Pasar Tunggal Eropa misalnya, diperkirakan akan membawa kesulitan baru di bidang perdagangan industri TPT, yakni dengan akan diadakan Regrouping Operational industri TPT di ME, dan dengan dihapuskannya Custom barriers industri TPT antara negara-negara ME, diperkirakan akan mampu menekan cost 8-10\%.

Regrouping industri tekstil Eropa direncanakan akan diarahkan ke daerah Mediterania yang memiliki ongkos tenaga kerja lebih rendah dan tersedia banyak tenaga kerja. Konsekwensi dari regrouping ini menunjukkan adanya era baru industri tekstil di Eropa yang akan dapat mampu bersaing di pasaran intemasional.

NAFTA, yang akan segera diberlakukan secara efektif mulai Januari tahun depan. Untuk tahun pertama akan menghapuskan barrier ekspor TPT AS sebesar $20 \%$, atau senilai US $\$ 250$ juta kepada Mexico.Penghapusan barrierekspor tersebut akan berlaku selama 6 tahun sampai 1999 dengan total penghapusan sebesar US $\$ 700$ juta. Sementara untuk negara-negara lain di Amerika Utara selain Mexico, barrier ekspomya akan dihapuskan oleh AS sampai tahun 2003. Kebijaksanaan perdagangan seperti ini jelas akan membawa keuntungan kepada produsen TPT di blok Amerika Utara dan AS saja, sementara produsen TPT di blok-blok lain hanya akan gigit jari.

Isu terbaru yang mungkin dapat mengancam industri TPT Indonesia (mungkin juga negara lain) adalah dengan akan dihentikan status Generalized System of Preferences (GSP) oleh AS. GSP adalah 
keringanan yang diberikan oleh pemerintah AS bagi ekspor dari negara-negara berkembangyang dapatmasuk ke AS secara bebas bea (duty free). Status GSP mulai diberikan AS untuk serangkaian negara berkembang tahun .1974, untuk jangka waktu 10 tahun.

Adanya tuduhan terhadap pelanggaran hak-hak buruh industri TPT Indonesia, pemerintah AS mengancam akan menghentikan pemberian fasilitas GSP bagi Indonesia. Jika ancaman ini betul terlaksana, maka ekspor TPT Indonesia ke AS akan diberhentikannya GSP terhadap Indonesia perlu dilakukan.

\section{Kesimpulan}

Sepuluh tahun terakhir ini laju relokasi industri tekstil dunia dari negaranegara maju ke negara-negera berkembang berjalan sangat cepat. Namun demikian, dengan berkembangnya teknologi yáng dimiliki industri ini dan low-tech menjadi high-tech akan merupakan karakter industri ini yang semula bersifat labour intensive industry menjadi high capital industry. Dengan berubahnya karakter tersebut, dalam dua atau tiga dasa warsa méndatang diperkirakan industri tekstil dunia akan -mengalami relokasi orde kedua dari negaranegaraberkembang ke negara-negara maju.

Walaupun neraca perdagangan TPT Indonesia menunjukkan surplus dalam waktu delapan tahun terakhir ini, tetapi nilai ketergantungannya terhadap impor masih tinggi, yakni 45,7\% dari total nilai ekspor. Ketergantungan tersebut meliputi: Barang-barang tekstil jenis khusus (14.8 $\%$; Permesinan (12,3\%); Bahan baku terutama kapas (12,1\%); dan Bahan-bahan kimia dalam proses dyeing, finishing dan printing $(4,7 \%)$.

Indonesiamasihmempunyai peluang yang cukup besar untuk dapat mengembangkan industri TPT, mengingat masih terbukanya peluang pasar internasional yang cukup besar. Peluang tersebut dapat diraih apabila industri TPT kita mampu mengatasi kendala-kendala: Pertama, mengurangi segala hambatan yang ada baik tarif maupun non-tarif dari negara pengimpor melalui negoisasi dan loby, baik bilateral, regional maupun multilateral, agarakses pasar TPT Indonesia ke negera tersebut semakin besar. Kedua, meningkatkan daya saing dan nilai tambah dari setiap kategori TPT melalui diversifikäsi, peningkatan efisiensi, dan peningkatan mutu produk dan pelayanan.

Disamping itu, dengan keadaan alamnya yang subur dan kekayaannya yang melimpah, Indonesia sesungguhnya memiliki potensi yang cukup besar untuk mengembangkan industri tekstilnya ke tingkat yang lebih maju. Adanya kebijaksanaan Hutan Tanaman Industri (HTI) yang diajukan oleh pemerintah misalnya, akan merangsang adanya hutanhutan Pintis dan tanaman Ramie, yang dapat digunakan sebagai bahan baku serat tekstil. Juga, terus dikembangkannya industri petrokimia dalam negeri beberapa tahun terakhir ini, akan memungkinkan pengembangan industri tekstil dari bahan sintelik yang akan memiliki keunggulan kompetitip. Dan sebagai karakternya industri TPT yang labour intensive, Indonesia yang memiliki cukup tenaga kerja dengan sendirinya akan memiliki keunggulan komparatif dalam industri tersebut.

Namun demikian, dengan adanyaera globalisasi, industri TPT yang merupakan industri global, dalam perkembangannya dimasa-masa mendatang diprakirakan akan tidaksemudah seperti di masa lalu. Adanya markets regionalisme baru, berubahnya 
sistim politik dan tanaman ekonomi di beberapa negara, merupakan kendalakendala yang perlu kita cermati dan kita carikan solusi.

Cost of Fund yang tinggi, proses perizinan investasi dan prosedur ekspor/ impor yang masih berbelit-belit, sumber daya manusia yang kurang memadai, serta sarana dan prasarana yang masih lemah, merupakan hambatan-hambatan dari dalam negeri yang perlu segera diatási untuk meningkatkan perkembangan industriTPT Indonesia.

\section{Daftar Bacaan \\ Rusdi, S. and Moerdoko, W., An Outline of The Textile Investment in Indonesia, Proceeding of The Asia and Word Textile Conference, Hongkong, May 1993.}

Moerdoko, W. and Rusdi, S., Current Situation of The Textile Industry in Indonesia, Proceeding of The Asia and World Textile Conference, Hongkong, May 1993.

Moerdoko, W: and Rusdi, S., Prospek Perkembangan Industri Tekstil di Masa Yang Akan Datang, Lokakarya Bank B APINDO, Bandung, Agustus 1993.

Anson, R., Globalisation of Supply, Markets and Personel in the World Clothing Industry, Proceeding of The International Conference on Industry and Education for Fashion and Clothing, The Textile Institute, 1990. Geerdes, J., Global Fibver Trend, International Fiber Journal, February 1993 , p. 5.

Hartman, U., Trend in Textile Capacity, Textile Asia, July 1993, p. 66.

------, Cotton in 1992-94, Textile Asia February 1993, p. 110.
Djafri, C., Industri Pertekstilan, Perkembangan Produksi dan Pemasarannya, Dialog Tekstil Nasional II Asosiasi Perteksilan Indonesia, April 1993.

Sung, K., Per capute Fibre Consumption 2000, Textile Asia, May 1993, p. 12.

Sung, K., Asian Textile 2000, Textile Asia, June 1993; p. 94.

Opay, P.P., A-review of the '80s and a Preview of the '90s for ATME-I 1992, International Fiber Joumal, August 1992, p. 19.

Brasher, D., Suppliers Coming Up, Textile Asia, january 1993, p. 15.

-..-., Outlook for US Industrial Fabrics and Fibers Through the Year 2000, International Fiber Joumal, June 1993, p. 36.

Schwartz," R., Imports Rebound, Textile Asia, June 1993, p. 15.

Leung, P., Good Yearin View, Textile Asia, March 1993, p. 67. , Thai Textile Industry in 1993, Japan Textile News, March 1993, p. 79.

Sahardjo, S., Pokok-pokok Sambutan Menteri Perindustrian Pada PembukaanDialog TekstilNasional, API, April 1993.

Sung, K., Indonesia, Leader in Poly, Textile Asia, March 1993, p. 112.

Millington, J.T., World News, American Textil Institute, August 1992, p. 28. O'Day.P.T., US Fibers 2000, Textile Asia, August 1992, p. 101.

Guobiao, Ji., Manmade Fibre in China, Textile Asia, August 1992, p. 97.

Yao, S.C.,PolyesterinTaiwan,TextileAsia, May 1993, p. 131.

, Study on Textile, Overview, Prospect and Companies Profile, $\mathrm{CIC}$, 1993. 